Article

\title{
Geography Pre-Service Teachers' Perspectives on Multimedia Technology and Environmental Education
}

\author{
Fengtao Guo ${ }^{1}$, Michael E Meadows ${ }^{1,2,3}{ }^{\mathbb{D}}$, Yushan Duan ${ }^{1, *}$ and Changhai Gao ${ }^{4}$ \\ 1 School of Geographic Sciences, East China Normal University, Shanghai 200241, China; \\ ftguo@geo.ecnu.edu.cn (F.G.); michael.meadows@uct.ac.za (M.E.M.) \\ 2 Department of Environmental \& Geographical Science, University of Cape Town, \\ Rondebosch 7701, South Africa \\ 3 College of Geography and Environmental Sciences, Zhejiang Normal University, Jinhua 321004, China \\ 4 School of Resources Environment and Tourism, Anyang Normal University, Anyang 455000, China; \\ 00497@aynu.edu.cn \\ * Correspondence: ysduan@geo.ecnu.edu.cn; Tel.: +86-137-0171-5221
}

Received: 10 July 2020; Accepted: 24 August 2020; Published: 25 August 2020

\begin{abstract}
Multimedia technology (MT) is now widely used in primary and secondary classrooms and has excellent potential for environmental education. The discipline of Geography has strong synergies with environmental education. The paper uses the $Q$ methodology to investigate the responses of pre-service geography teachers regarding the use of multimedia in environmental education (EE). The viewpoints of respondents were clustered into three broad perspectives relating to the use of multimedia: Perspective 1: the use of multimedia is regarded as valuable but difficult to apply; perspective 2: the use of multimedia is rewarding and practicable; perspective 3: the use of all types of multimedia is seen as highly valuable, although in the case of GIS the attitude is more equivocal. All three perspectives align with the idea that MT can improve EE, although the respondents suggest it cannot be a direct replacement for fieldwork. While all three perspectives are consistent with the view that multimedia teaching has many functional advantages in relation to environmental education, concerns are expressed regarding teachers' capacity to fulfill its potential. The authors suggest that understanding these perspectives can help improve pre-service teacher education and advance environment education in middle school.
\end{abstract}

Keywords: environmental education; Information and Communication Technology; multimedia teaching; Q methodology

\section{Introduction}

As a consequence of the COVID-19 pandemic, education institutions from pre-primary to university all over the world were forced to close, and multimedia teaching methods delivered over the internet became the norm in school education. Despite the obvious negative effects of school closure, the situation required educators to deploy multimedia technology (MT) in online classes and, in so doing, this offered an opportunity to develop multimedia resources that could be used and refined in future. In relation to environmental education (EE), the outbreak of the coronavirus pandemic is a kind of alarm bell from nature, and can make us think more deeply about the relationship between humans and the environment. The pandemic not only prompted the use of online education but also played an important role in the form of outreach media [1] and added further emphasis to the call for all countries to adopt EE for sustainable development [2].

In China, as in many countries, EE is not taught as an independent subject in the curriculum and is integrated into the topics of "nature" at elementary school, and into "geography" in secondary 
schools [3]. The action themes of Education for Sustainable Development (ESD; 2005-2014) include overcoming poverty, gender equality, health promotion, environment, rural development, cultural diversity, peace and human security, and sustainable urbanization [4]. ESD represents the shift toward greater anthropocentric orientation in EE [5]. However, the early understandings of EE that focused on the protection of natural environment should be retained in ESD. Geography, therefore, is central to the idea of implementing education for sustainable development. The EE content of the geography curriculum is clearly reflected in the content standards and textbooks at middle school level in China [6]. Therefore, it is important to establish the perceptions and literacy of geography pre-service teachers in relation to EE. Effective EE requires that teachers have adequate levels of environmental literacy, i.e., the knowledge, skills, and dispositions to solve problems and resolve issues individually and collectively that sustain ecological, economic, and social stability. Moreover, if they are going to be able to embrace MT in the context of EE, they must also have the relevant technical skillset. However, many studies have reported that pre-service teachers are not trained or even encouraged to use MT technologies to improve instruction and student engagement [7-9]. Although there are many studies about the potential and disadvantages of MT to EE, there have been no previous studies of the attitudes of pre-service teachers' toward incorporating MT in EE. MT is increasingly used in EE and is facilitated by the widespread availability of digital technology. Nevertheless, there are few courses for pre-service geography teachers that explicitly deal with EE. In addition, due to safety and other reasons, the method of fieldwork and field investigation is difficult to implement in EE, and therefore other forms of bringing the field to the classroom have to be used. With the development of the ICT, MT is a pedagogical innovation and a potentially new teaching method for EE. Given that the discipline of Geography is so central to EE, assessing the nature of trainee geography teachers' attitudes to MT in general, and to its use in EE in particular, is valuable. In principle, it is anticipated that geography students who have been exposed to MT will be more likely to find MT valuable and apply these methods in the EE context. Exploring their perceptions of MT in EE is a way of evaluating the assumption that they will more easily engage with information technology in their teaching. Among pre-service teachers, the levels of environmental literacy, attitudes toward MT, and their potential to develop the EE curriculum using MT are largely unknown. Therefore, a four-month undergraduate module for undergraduate sophomore geography students at East China Normal University was presented in the early part of 2020. The course was designed to develop MT skills in these pre-service teachers and to enable them to make use of multimedia courseware with potential application to EE. The aim of this paper is to explore the attitudes of the course participants toward the use of MT, specifically in the context of EE. In order to achieve this aim, we set the following objectives:

(i). To identify a comprehensive set of descriptive "statements" about the use of MT in EE;

(ii). To assess the responses of the course participants to these statements (i.e., levels of agreement or disagreement);

(iii). To conduct the analysis of the responses using a suitable methodological tool;

(iv). To evaluate the perception of the course participants about the use of MT in EE;

(v). To develop a set of recommendations for pre-service teaching training in MT in relation to EE.

\section{The Use of MT in EE}

The past three decades have witnessed the rapid proliferation of computers and the internet, which has profoundly changed many aspects of human activities [10]. ICT enables the application of multimedia technology (MT) to teaching and has rapidly become an important part of the contemporary social structure [11]. For almost every country, understanding and mastering MT has become one of the core issues in education [12], and, indeed, China has released its policy initiative National Plan for Medium and Long-Term Education Reform and Development to accelerate its digital educational process [13]. The Action Plan for Education Informatization 2.0 proposes to realize the availability and use of MT for all teachers and students, and the construction of a digital campus in all schools by 2022 . 
This initiative goes hand in hand with the goal of improving the MT literacy of teachers and students and to construct a new mode of talent cultivation under the condition of what is known as "internet plus" [14].

The benefits of MT in improving the quality of education and skill levels among students are widely acknowledged [15-18]. MT can facilitate the work of the teacher through its use as a cognitive tool [19-21], an investigative tool, as a regulatory instrument, as a communication tool, and as an information search tool [22]. By using cognitive tools in a constructive framework, learners engage in a variety of critical, creative, and complex thinking opportunities [23,24]. MT has clearly been demonstrated to play a positive role in enriching and improving students' skills, in accelerating learning, fostering motivation, and helping learners to connect theoretical knowledge with practical issues and continues to develop into an essential learning tool [25]. Educators have also been focusing on the paradigm shift from traditional teaching methods to modern teaching methods in order to create an effective environment conducive to students' learning [26]. Multimedia takes diverse forms that can be exploited in education. Video annotations, for example, have been used successfully to improve the learning of complex concepts in diverse subjects, such as Physics [27] and English Language [28], among school learners and pre-service teachers [29]. We now provide some examples of why and how MT has been used in EE. Other studies have highlighted the need for, and advantages of, pre-service teachers acquiring IT skills, so that they can incorporate MT into their teaching [30]. The use of video, in particular, has been shown to promote students' learning and to support traditional study, for example by improving the understanding of unfamiliar environments (Hill and Nelson, [31]).

Although the integration of MT into education may seem very promising, there are still some fundamental questions around the misapplication, inequity of access, etc., that lie at the heart of the emerging field of computer-aided EE [32]. Such questions may be partly attributed to the discrepancies between existing theories and actual factors that influence teachers' willingness and ability to adopt MT [33]. There are several factors underlying the acceptance of MT in relation to EE in particular, viz., (a) perceived usefulness [33], (b) perceived ease of use [34], (c) perceived enjoyment [35], (d) technology self-efficacy [36,37], (e) subjective norms [38-40], and (f) facilitating conditions [41]. In addition, teacher pedagogical beliefs [42-44], attitudes toward technology [45], the educational experiences of the teachers, and internal barriers [46] also influence the integration into EE.

Several studies have been undertaken to develop pre-service teachers' ability to use MT in their teaching. There is established research that indicates that the technological pedagogical content knowledge (TPACK) of teachers is the contributing factor that determines MT integration and transforms learning [47]. Researchers have developed instruments to investigate pre-service teachers' perceptions of their TPACK in various contexts toward developing multimodal literacies [48,49].

There are many studies exploring the impact of different teaching strategies on the learning performance of environmental education, using WebQuest [50], picture books [51], project-based learning approach [52,53], problem-based learning [54], field-based/outdoor environmental education program [55] or fieldwork [56].

EE and MT share the potential to support critical and action-oriented problem-based learning in the promotion of the understanding of sustainability. Given that MT and EE can both promote innovation in the field of education, EE appears to be a promising platform in which to integrate these tools [57]. Research suggests that MT offers an array of powerful tools that have the potential to transform the teaching and learning processes and foster new modes of learning for sustainability $[17,58]$. Indeed, MT presents a whole new set of extremely powerful ways of promoting, perhaps as never before, the goals and objectives of EE [32,59]. Therefore, the use of MT in EE can help teachers to harness the power of computers to integrate multimedia and to improve student awareness $[18,19]$. At the same time, teachers help learners to understand their own environment and its associated problems. Nevertheless, there remains a paucity of research regarding the attitudes and preparedness of pre-service teachers to adopt multimedia-aided EE. 


\section{Methodology}

This research is based on the outcomes of a four-month online course, "Multimedia Geography Teaching and Courseware", presented to sophomore Geography students at East China Normal University, in Shanghai, China. It is one of the key courses in the teacher training program and the only one that explicitly focuses on MT and EE. The objective of the course was to cultivate geography pre-service teachers' ability of MT, that is, how to use MT to make courseware in EE. It consisted of several parts, as follows: geographical education and EE (content, including references to the pandemic), multimedia design principles, multimedia courseware design steps, introduction and use of the iebook software; multimedia resource search related to geography and environment, courseware display and discussion, revision of content design and geographic information technology, courseware modification, presentation, and peer evaluation. The student should learn multimedia design principles, multimedia courseware design steps, and the use of the iebook software, and then produce courseware by searching for different multimedia teaching resources, such as text, audio, images, animations, video, and interactive content in the iebook software.

At the end of the course, the students were subjected to a survey designed using $Q$ methodology. Q methodology is a research tool, developed by the psychologist William Stephenson in the 1930s, and is widely used in psychology and the social sciences as a means of revealing issues of subjectivity [60]. It contains a series of unique psychological measurement and operational principles and helps to unpack the complexity involved in human subjectivity. $Q$ methodology is based on two preconditions: 1. Subjective viewpoints are communicable, and 2. The subjective viewpoints are derived from "self-reference" [61]. Researchers are able to apply quantitative analysis to detect and classify the range of subjective elements of human behavior [61].

\subsection{Selecting the $Q$ Sample Statements}

Q samples can be combined to create hybrid samples [61]. The author obtained more than 110 opinion statements on the relationship between EE and MT, mostly through an internet search and partly through publications. Only little viewpoints were supplemented by canvassing additional comments from the student participants themselves via the online communication platform known as "Blackboard" [62], in order to ensure that the widest possible range of relevant aspects of the topic are explicitly discussed [61]. The overall objective of the study was, in essence, to explore pre-service geography teacher perceptions of MT in the context of EE. In addition, it was decided to include some statements about Geography Information Systems (GIS), and EE in particular, in order to assess, as did [22], whether or not the respondents favor the use of GIS in EE. After initially eliminating statements with similar meaning or considered to be less relevant, the sample viewpoints were reviewed by experts and peers to ensure clarity of language and that they were sufficiently comprehensive in representing the possible range of opinions [61]. "Less relevant" refers to statements that were initially derived from various sources but were considered as insufficiently directed toward the relationship between MT and EE, and were therefore omitted. On this basis, the final set of 44 statements was classified into seven categories, each containing 4-6 statements. As can be seen in Table 1, these are: the need for MT, comparison with other teaching methods, disadvantage and advantages of MT, the role of MT in student environmental literacy, the role of GIS in EE, and external factors. 
Table 1. Statements in the Q-set.

\begin{tabular}{|c|}
\hline \# Statements \\
\hline The need for Multimedia Technology (MT) \\
\hline 1. EE urgently needs to adopt MT \\
\hline 2. MT is the best way to teach EE \\
\hline 3. MT can improve EE \\
\hline 4. MT supports student knowledge construction \\
\hline Comparison with other teaching methods \\
\hline 5. MT is better than traditional teaching methods \\
\hline 6. MT in teaching cannot replace other forms of teaching \\
\hline 7. Students prefer MT \\
\hline 8. MT is more effective than field environmental activities \\
\hline 9. Multimedia simulation is easier to use \\
\hline 10. MT in teaching cannot become a daily EE method \\
\hline Disadvantages of MT \\
\hline 11. MT is divorced from the actual living environment \\
\hline 12. MT encourages teachers to suspend their regular teaching methods \\
\hline 13. MT is a form of entertainment and does not help achieve EE learning objectives \\
\hline 14. Making MT courseware increases the burden on teachers \\
\hline Advantages of MT \\
\hline 15. MT courseware is more environmentally friendly than paper resources \\
\hline 16. MT is able to meet a wider range of student learning needs \\
\hline 17. MT is easily used to promote EE \\
\hline 18. MT courseware arouses students' emotions about the environment \\
\hline 19. MT courseware improves students' learning efficiency in general \\
\hline 20. MT can be used to simulate environmental processes and events \\
\hline 21. MT is convenient to communicate environmental issues \\
\hline 22. MT mobilizes student learning initiatives \\
\hline 23. MT is beneficial to the development of EE resources in secondary schools \\
\hline 24. MT broadens the cognitive approach to the environment \\
\hline 25. MT courseware is easy to modify and update \\
\hline The role of MT in student environmental literacy \\
\hline 26. MT improves the students' learning interest \\
\hline 27. MT is conducive to improving students' environmental awareness \\
\hline 28. MT promotes active participation by students in environmental protection activities \\
\hline 29. MT courseware helps to explain difficult environmental concepts \\
\hline 30. MT courseware improves students' ability to solve environmental problems \\
\hline 31. MT courseware promotes students' creativity \\
\hline 32. MT courseware improves students' awareness of environmental aesthetics \\
\hline 33. MT cultivates the understanding of the relationship between humans and the earth \\
\hline 34. MT enhances an appreciation of social responsibility \\
\hline 35. MT cultivates critical thinking \\
\hline 36. MT promotes the personal development of students \\
\hline The role of GIS in EE \\
\hline 37. The visualization and analysis of spatial data in GIS relates directly to EE \\
\hline 38. Using GIS data sources can promote EE \\
\hline 39. GIS effectively contributes to EE through the creation maps \\
\hline 40 . It is difficult to apply GIS to EE \\
\hline External factors \\
\hline 41. Teachers' information literacy will impact the effect of EE \\
\hline 42. Existing MT software is unable to meet the needs of EE \\
\hline ols in most areas of China have the necessary facilities to teach with MT \\
\hline 44. Technical skill levels required to operate MT courseware restrict the potential of MT \\
\hline
\end{tabular}

\subsection{Q-Sort and Interview Method}

Due to the impact of the pandemic, it was not possible to conduct face-to-face interviews, so the study was conducted online via the Tencent Meeting communication application. This study utilized the responses of the 27 geography pre-service students who were selected according to their willingness to participate and received no remuneration or other incentive. The students engaged in the study 
were sophomores between the ages of 19 and 22, and all but four of them were female. Although their homes were in a diverse range of places across China, and they were from urban, suburban, and rural areas, all students were enrolled in the pre-service teacher program for geography and will be qualified as geography teachers in middle school after graduation. It is likely, based on past experience, that most will teach geography in senior middle school.

The participants were divided into eight groups, and each was presented with a MSWord document consisting of six parts, that included a brief interview guide, two preliminary questions, 44 statements, a Q-score sheet (see Figure 1), and five post-sorting questions. The survey took approximately $70 \mathrm{~min}$ to complete.

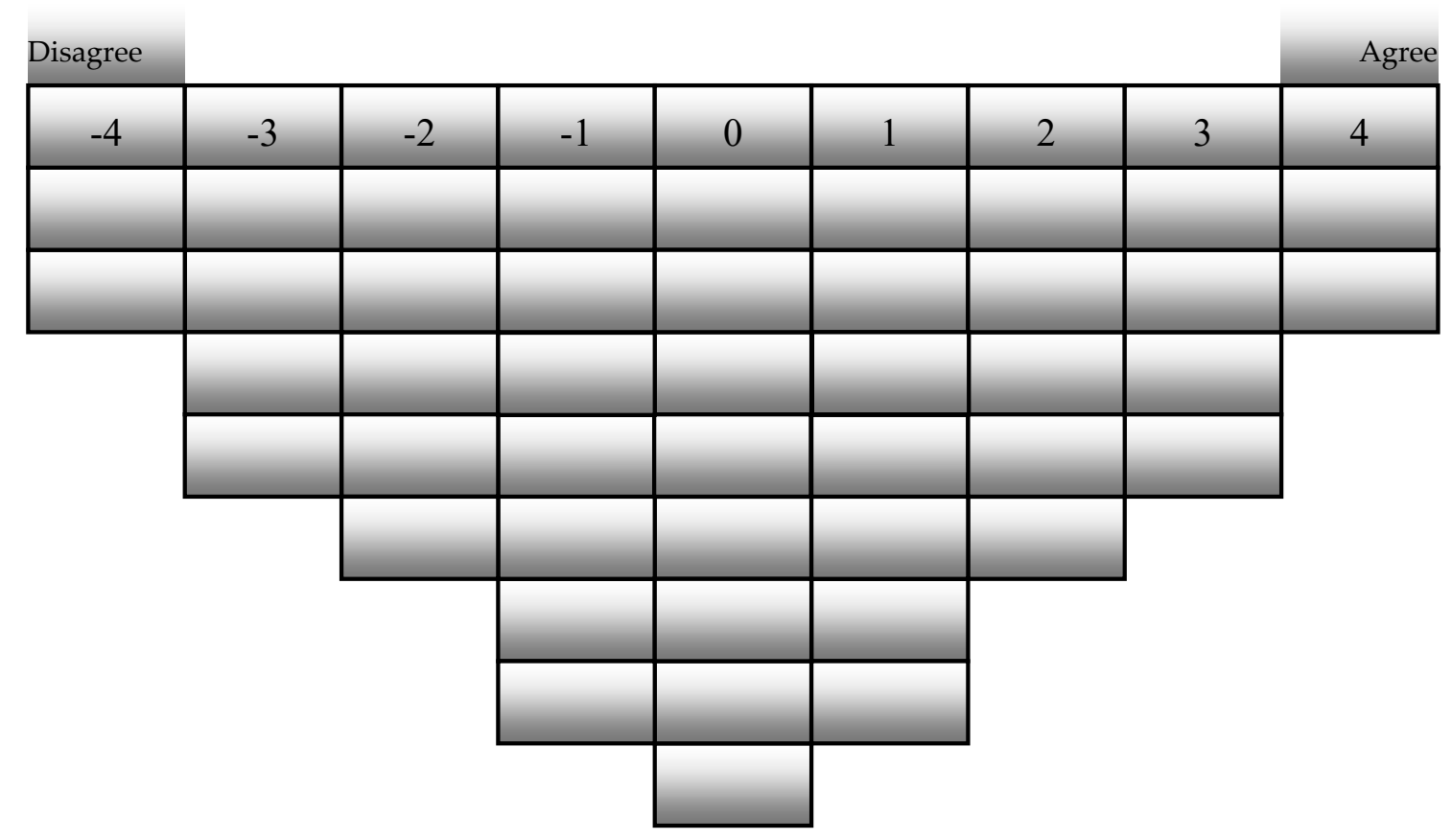

Figure 1. Q-score sheet.

\subsection{Conducting the Q-Sort}

Before sorting, the purpose of the study was explained to the participants. The participants were encouraged to choose the viewpoints from their own perspective and not simply agree/disagree according to "official" viewpoints. Two open questions were asked before formal sorting, viz., (a) briefly outline what you understand about the relationship between geography education and environmental education; and (b) do you agree that MT will have an effect on EE? If so, how? If not, why? These two questions were designed to help adjust the mindsets of the participants. Instructions for completion of the Q-sort were then given as follows: (i) carry out the survey in a quiet environment; (ii) after carefully reading the statements, classify each one into three categories, viz., agree, disagree, unsure; (iii) select the two statements that you most strongly agree with and place these in the column under the +4 marker; (iv) highlight these two statements in order to facilitate their later selection; (v) as in (iv) above, select and highlight the two statements that you most strongly disagree with; (vi) continue as above, progressively selecting the remaining statements that you most strongly agree/disagree with and place them in the appropriate box. The participants were then asked to send a 60 -s voice message via WeChat, which was then transcribed, or to write a brief comment. Finally, the instructor conducted a short interview with the participants, asking them to explain their sorting of viewpoints [63]. The interview consisted of five questions as follows: (1) Please explain why you most strongly agree with the two viewpoints in column +4 . (2) Why do you most strongly disagree with the two viewpoints in column 
-4 ? (3) Why do you agree with the four viewpoints in column +3 ? (4) Why do you disagree with four viewpoints in column -3? (5) What other points would you like to make?

\subsection{Data Processing}

PQMethod version 2.3 [64] was used to perform factor analysis. Principal Component Analysis was used initially, and the final outputs of a varimax routine compared. Based on the criteria of simplicity, clarity, distinctiveness, and stability [65], the result of three-factor rotation was selected. Following rotation, the software identifies individual sorts that are representative of a particular factor (see Supplementary Materials, Appendix A). The method indicated which respondents agreed with each factor, and by how much.

\subsection{Data Analysis}

Generating descriptions of social perspectives is "something of an art" [65]. Factor interpretation proceeds primarily in two ways, by (i) noting the objects that have significant factor loadings (see Supplementary Materials, Appendix A), and (ii) by attending to the factor scores of $Q$ sample items characterizing the factor [61]. Firstly, the individual participants' sorts are examined carefully and the transcript of the interview ordered according to the factor/statement they most closely represent. Secondly, the data output file generated by the PQMethod to examine the Normalized Factor Scores of each statement enables the identification of the statements most representative of each factor [66]. Statements which rank +3 or higher, and -3 or lower, were used to interpret the meaning of each factor, as they indicate the statements that most strongly distinguish each factor (Tables 2-4). It is then possible to assess which factors the respondents rate as most important. References to the comments made during the interview further assist in interpreting the factor loading (see Appendix A) and enable the researcher to derive the final list of perspectives, which are then reviewed.

Table 2. Top ranked and distinguishing statements for factor 1 .

\begin{tabular}{cccc}
\hline No. & Statement & $\begin{array}{c}\text { Normalized } \\
\text { Factor Scores }\end{array}$ & Z-Score \\
\hline & Top ranked statement scores for Factor 1 & 4 & 1.733 \\
21 & MT is convenient to communicate environmental issues & 4 & 1.600 \\
3 & MT can improve EE & 3 & 1.509 \\
15 & MT courseware is more environmentally friendly than paper resources & 3 & 1.447 \\
41 & Teachers' information literacy will impact the effect of EE & 3 & 1.262 \\
17 & MT is easily used to promote EE & 3 & 1.167 \\
20 & MT can be used to simulate environmental processes and events & -3 & -1.360 \\
43 & Schools in most areas of China have the necessary facilities to teach with MT & -3 & -1.369 \\
13 & MT is a form of entertainment and does not help achieve EE & -3 & -1.653 \\
12 & learning objectives & -4 & -1.860 \\
8 & MT encourages teachers to suspend their regular teaching methods & & $1.04^{*}$ \\
14 & MT is more effective than field environmental activities & 2 & $0.58^{*}$ \\
6 & Distinguishing statements for Factor 1 & 1 & $-1.40^{*}$ \\
1 & Making MT courseware increases the burden on teachers & -3 & $-2.05^{*}$ \\
\hline
\end{tabular}

Note: $p<0.05$; Asterisk $\left(^{*}\right)$ Indicates Significance at $p<0.01$. 
Table 3. Top ranked and distinguishing statements for factor 2.

\begin{tabular}{|c|c|c|c|}
\hline No. & Statement & $\begin{array}{l}\text { Normalized } \\
\text { Factor Scores }\end{array}$ & Z-Score \\
\hline & Top ranked statement scores for Factor 2 & & \\
\hline 15 & $\begin{array}{c}\text { MT courseware is more environmentally friendly than } \\
\text { paper resources }\end{array}$ & 4 & 1.743 \\
\hline 4 & MT supports student knowledge construction & 3 & 1.489 \\
\hline 3 & MT can improve EE & 3 & 1.038 \\
\hline 2 & MT is the best way to teach EE & -3 & -0.965 \\
\hline 34 & MT enhances an appreciation of social responsibility & -3 & -0.990 \\
\hline 31 & MT courseware promotes student creativity & -3 & -1.041 \\
\hline 11 & MT is divorced from the actual living environment & -3 & -1.819 \\
\hline 13 & $\begin{array}{c}\text { MT is a form of entertainment and does not help achieve EE } \\
\text { learning objectives }\end{array}$ & -4 & -1.898 \\
\hline 8 & $\begin{array}{l}\text { MT is more effective than field environmental activities } \\
\text { Distinguishing statements for Factor } 2\end{array}$ & -4 & -2.519 \\
\hline 43 & $\begin{array}{l}\text { Schools in most areas of China have the necessary facilities to } \\
\text { teach with MT }\end{array}$ & 4 & 2.16 * \\
\hline 16 & MT is able to meet a wider range of student learning needs & 3 & 1.70 * \\
\hline 25 & MT courseware is easy to modify and update & 3 & 1.54 * \\
\hline 5 & MT is better than traditional teaching methods & 2 & $0.83 *$ \\
\hline 9 & Multimedia simulation is easier to use & 2 & $0.80 *$ \\
\hline 41 & Teachers' information literacy will impact the effect of EE & 1 & $0.51 *$ \\
\hline 21 & MT is convenient to communicate environmental issues & 0 & $0.20 *$ \\
\hline 17 & MT is easily used to promote EE & -1 & -0.31 * \\
\hline
\end{tabular}

Table 4. Top ranked and distinguishing statements for factor 3.

\begin{tabular}{|c|c|c|c|}
\hline No. & Statement & $\begin{array}{l}\text { Normalized } \\
\text { factor scores }\end{array}$ & Z-Score \\
\hline & Top ranked statement scores for Factor 3 & & \\
\hline 17 & MT is easily used to promote EE & 3 & 1.469 \\
\hline 3 & MT can improve EE & 3 & 1.351 \\
\hline 21 & MT is convenient to communicate environmental issues & 3 & 1.348 \\
\hline 41 & Teachers' information literacy will impact the effect of EE & 3 & 1.323 \\
\hline 11 & MT is divorced from the actual living environment & -3 & -1.205 \\
\hline 12 & $\begin{array}{c}\text { MT encourages teachers to suspend their regular } \\
\text { teaching methods }\end{array}$ & -3 & -1.257 \\
\hline 37 & $\begin{array}{c}\text { The visualization and analysis of spatial data in GIS relates } \\
\text { directly to EE }\end{array}$ & -3 & -1.304 \\
\hline 43 & $\begin{array}{c}\text { Schools in most areas of China have the necessary facilities to } \\
\text { teach with MT }\end{array}$ & -3 & -1.331 \\
\hline 8 & $\begin{array}{l}\text { MT is more effective than field environmental activities } \\
\text { Distinguishing statements for Factor } 3\end{array}$ & -4 & -2.194 \\
\hline 20 & $\begin{array}{l}\text { MT can be used to simulate environmental processes } \\
\text { and events }\end{array}$ & 4 & $1.86^{*}$ \\
\hline 26 & MT improves the students' learning interest & 4 & $1.68 *$ \\
\hline 38 & Using GIS data sources can promote EE & -2 & -0.76 * \\
\hline 36 & MT promotes the personal development of students & -2 & -1.17 * \\
\hline 37 & $\begin{array}{c}\text { The visualization and analysis of spatial data in GIS relates } \\
\text { directly to EE }\end{array}$ & -3 & $-1.30 *$ \\
\hline 10 & MT in teaching cannot become a daily EE method & -4 & -1.74 * \\
\hline
\end{tabular}

Note: $p<0.05$; Asterisk $\left(^{*}\right)$ Indicates Significance at $p<0.01$. 


\section{Results}

As evident in Tables 2-4, the three factors can be grouped into three broad perspectives.

\subsection{Perspective 1: MT Is Perceived as Valuable for Teaching EE, But It Is Difficult to Use}

Perspective 1 is shared by a relatively large proportion of the respondents (11/27). Although these respondents recognize the role of $\mathrm{MT}$ in $\mathrm{EE}$, this response is tempered by the observation that they do not agree that MT is the best way to promote EE (Statement 2), or that EE urgently needs to adopt MT (Statement 1). By way of example, here are some representative comments that reflect the respondents grouped into perspective 1 .

Respondent no. 6:

Undeniably, multimedia technology is a good way of promoting environmental education, but it is not indispensable, it has limitations, and it is not better than other ways.

Respondent no. 3:

I feel that MT is indeed very useful, but it is something of an armchair strategy. The role of MT and its range of applications have been exaggerated ...

This group contends that MT requires the acquisition of skills that take a lot of time and energy, and increases the teachers' workload. It was also highlighted that there are marked regional differences in China concerning the availability of appropriate facilities.

Respondent no. 4:

MT is definitely both a challenge and a burden for teachers.

Respondent no. 6:

Making multimedia courseware is not easy ... it takes a long time and energy to produce a beautiful, desired effect and satisfactory courseware.

Respondent no. 18 (from Inner Mongolia):

MT cannot be implemented in many areas.

\subsection{Perspective 2: MT Advances Student Learning in EE}

This perspective considers MT to be a very good way of teaching EE and that it may be better than traditional teaching methods (Statement 5), although they recognize that it cannot replace field study (Statement 8). This perspective highlights the importance of the availability of appropriate facilities but is of the view that these are generally available across schools in the country (Statement 43).

Respondent no. 5:

MT equipment is basically popular in China now. The requirements of multimedia equipment for EE are generally not high and can be adjusted according to the needs of teachers.

This perspective emphasizes the advantages of MT itself and notes, furthermore, that MT courseware is more environmentally friendly than paper resources and is easier to modify and update. This group perceives MT to be more than simply a form of entertainment.

Respondent no. 5:

Multimedia is not necessarily entertaining, although it depends on the teachers' selecting appropriate content and students' own interests, which are subjective factors.

Respondent no. 11:

Traditional education relies more on paper resources that may not be recycled. Content using MT can be modified and updated easily without impacting the environment.

This perspective also emphasizes the effect of MT as a cognitive tool that positively impacts on student learning. This is consistent with Mayer's (2001) learner-centered design, which promotes learning and improves knowledge construction. These respondents agree strongly that MT is able to meet a wider range of student learning needs (Statement 16), although they do not consider that it advances creativity (Statement 31) or social responsibility (Statement 34). 


\subsection{Perspective 3: MT Is a Highly Effective Tool in Advancing Student Learning in EE, Although the Application of GIS Is More Difficult}

This perspective has the most positive response to the perceived usefulness of MT as a tool to enhance EE. This is best illustrated by the strongly positive reaction to Statements 20 and 26, and the fact that they most negatively scored Statement 10 (see Table 4 ). Seven respondents, loaded prominently on this perspective, believe that MT can be used to simulate environmental processes and that it can be applied on a daily basis to improve students' interest in learning. For example:

Respondent no. 19:

Using multimedia in teaching methods can present information and resources through multiple channels to maximize students' interest and concern.

Through interaction, students' sense of participation and their learning interest in, and concern for, the environment can be further improved.

Respondent no. 13:

MT can promote students' awareness of environmental protection. It can help to better carry out EE in daily life.

Although this viewpoint is very strongly in favor of MT in EE, the respondents highlight some further challenges. For example, there is rather less certainty around the visualization and analysis of spatial data using GIS (Statements 37 and 38).

Respondent no. 13:

GIS is good at data management and operation analysis, but it still needs to be processed before it can be used in education. The data provided by GIS also need to be interpreted in order to convey ideas about the environment.

Reservations are also expressed concerning the availability of GIS technology in schools and the capacity of teachers to use it, given the complexity of geospatial data.

Respondent no. 8:

Students are only exposed to textbook maps or remote sensing images on TV or the internet... because of the difference in GIS' popularization rate or education, students lack access to the GPS databases of some authoritative observation sites.

Respondent no. 24:

GIS has little effect on EE for teachers who are not particularly good at its application. GIS is complicated in analysis, and it is challenging for students' understanding and cognitive ability. I think teachers should be able to explain the fundamentals in simple terms, it can be adopted appropriately, but not put the cart before the horse.

\section{Discussion}

The results of the Q-score exercise conducted with the 27 student participants indicate that there is a continuum of responses from those participants (Perspective 1) who feel that, although MT has great potential in teaching EE, it is difficult to apply, to those who embrace MT and are strongly in favor of using it consistently in the classroom (Perspective 3). In general, the study highlights the potential of MT in EE, and some respondents go as far as to say it is an essential element. However, there are some limitations noted, especially in relation to fieldwork, where many feel that exposure to real-world conditions beyond the classroom cannot be substituted for MT. Furthermore, while GIS is accepted as a valuable means of collating, analyzing, and interpreting geospatial data, the respondents are very uncertain about applying this in their teaching - and this despite the fact that they have all successfully passed a GIS module as part of their curriculum. This finding concurs with several recent research studies which question the benefits and learning outcomes of GIS [67-69]. This may be partly attributed to several challenges to incorporating GIS in secondary education [70-74] Challenges can be summarized as technological and societal [75]: for example, students may focus on technology rather than on geography while adapting GIS to the curriculum, which may lead to GIS becoming the actual aim in the teaching process instead of a mere tool [76]. The teachers also mentioned several potential 
problems, including their own shortcomings in using both computers and GIS, the lack of time allotted for such activities, inadequate computer skills, and the level of difficulty of GIS, since it has been found to be rather complex [77].

The geography and environmental education research community has perhaps still not fully embraced the potential contribution of GIS to substantive learning [78]. Without doubt, however, GIS education will be of increasing importance in the future. GIS may indeed make significant gains if environmental educators embrace the technology [75], and it will be essential for all geography teachers to develop adequate skills, a situation that should become more feasible as open-source GIS software becomes more user-friendly. For example, in the newly revised curriculum standard in 2017, GIS is strongly prevalent [79]

The uncertainty over GIS in the responses points perhaps to a more deep-seated issue among pre-service teachers. Multimedia literacy in general appears to be underdeveloped, a problem exacerbated by the inequitable distribution of MT resources in Chinese schools. It has been suggested that technology receives little attention in teacher education programs [80]. Consequently, their technological knowledge and the ability to use MT is in need of being strengthened overall in teacher education, not only from the perspective of EE [81]. Of course this begs the question as to what level of student and teacher information literacy should be expected. It is widely accepted that achieving high levels of competency in MT is time-consuming and labor-intensive, and it is probably unreasonable to expect teachers to acquire the skills to actually produce multimedia software and content. It is more realistic to train teachers in the use of software that is already developed and, in the context of the goal of sustainability, customized for EE. Courseware modules can be produced by a range of actors, including university research units, government agencies, environmental protection organizations, and commercial enterprises that can cooperate to promote the application of MT in environmental education.

Respondents grouped in Perspective 2 consider multimedia as a cognitive learning tool and that MT presentations do more than simply provide information, and can also guide students as to how to process the information. In other words, as in constructivism, MT can aid the process of knowledge construction [82]. This constructivist view is in many ways highly consistent with the well-established Guiding Principles of Environmental Education [83] and levels of environmental literacy [84].

Of course, pre-service teacher education should only focus not on how to use technology, but also on how technology intersects with pedagogical and content knowledge [85,86]. As Mishra and Koehler [87] advocate, it is only when teachers demonstrate the interplay of technological knowledge (TK), pedagogical knowledge (PK), and content knowledge (CK) that they can be effective in using technology to enhance their teaching practices. This study clearly emphasizes the need for improvements in teacher-education programs using MT to enhance EE.

\section{Conclusions}

Based on a 17-week undergraduate course aimed at guiding the students to develop EE courseware, the paper investigates empirically the levels of understanding and attitudes toward MT in relation to the EE of a cohort of geography pre-service teachers. Three related but distinctive perspectives are identified. The respondents grouped into Perspective 1, while recognizing the potential of MT, suggest that it is difficult to apply and that they are more likely to continue to use more traditional teaching methods. Those grouped in Perspective 2 are more supportive of applying MT in EE, considering that it offers a valuable cognitive tool for student learning, although they identify limitations in regard to fieldwork which cannot be easily replaced by a reliance on technology. Perspective 3 respondents are most strongly in support MT and consider that it can make a very valuable contribution to EE, although they are much less certain about the role of GIS.

Through its application of the $\mathrm{Q}$ method, this study offers a deeper understanding of pre-service geography teacher perceptions of the use of MT to enhance the effectiveness of EE. The results of this study indicate that, even after the completion of a short course introducing MT in the EE context, these 
prospective teachers still have variable opinions, and a substantial number of them remain uncertain as to its application, especially in relation to GIS. To move forward, improvements in pre-service teacher education programs in China are recommended. In particular, attention should be paid to the application of a constructivist learning theory and to developing MT skills in general and GIS competency in particular. Such interventions should help to harness the advantages of MT and promote EE in schools.

Supplementary Materials: The following are available online at http://www.mdpi.com/2071-1050/12/17/6903/s1.

Author Contributions: Conceptualization, F.G. and M.E.M.; methodology, F.G.; software, F.G.; validation, M.E.M., Y.D. and F.G.; formal analysis, F.G.; investigation, M.S, and F.G.; resources, C.G. and F.G.; data curation, Y.D.; writing —original draft preparation, F.G.; writing—review and editing, M.E.M.; visualization, F.G.; supervision, M.E.M.; project administration, Y.D. All authors have read and agreed to the published version of the manuscript.

Funding: This research received no external funding.

Acknowledgments: We acknowledge the help of Joseph P. Stoltman at Western Michigan University, and Yu Lizhong, at East China Normal University. We thank Mengliao Shen for helping in the investigation and data collection.

Conflicts of Interest: The authors declare no conflict of interest.

\section{Appendix A}

Table A1. Factor matrix with an $\mathrm{X}$ indicating a defining sort.

\begin{tabular}{|c|c|c|c|}
\hline \multirow[t]{2}{*}{ Participant\# } & \multicolumn{3}{|c|}{ Factor } \\
\hline & F1 & F2 & F3 \\
\hline 1 & 0.5692 & 0.5840 * & -0.1007 \\
\hline 2 & 0.4821 & 0.4696 & 0.2394 \\
\hline 3 & 0.7391 * & 0.1923 & 0.3725 \\
\hline 4 & 0.6829 * & 0.1292 & 0.4911 \\
\hline 5 & 0.0032 & $0.6882 *$ & 0.2590 \\
\hline 6 & 0.8328 * & 0.0199 & 0.0387 \\
\hline 7 & $0.6802 *$ & 0.2846 & 0.2524 \\
\hline 8 & 0.1148 & 0.1717 & 0.6538 * \\
\hline 9 & 0.2488 & 0.4859 * & 0.3507 \\
\hline 10 & 0.5639 & 0.5167 & 0.3056 \\
\hline 11 & 0.1746 & 0.6933 * & 0.4061 \\
\hline 12 & 0.6189 * & 0.2887 & 0.4742 \\
\hline 13 & 0.3490 & 0.2189 & 0.6015 * \\
\hline 14 & 0.5891 * & 0.1351 & 0.4136 \\
\hline 15 & 0.5759 & 0.1594 & 0.6000 * \\
\hline 16 & 0.0423 & 0.4077 & 0.5129 * \\
\hline 17 & 0.5579 * & 0.3239 & 0.2221 \\
\hline 18 & 0.6757 * & 0.0878 & 0.0857 \\
\hline 19 & 0.4813 & 0.0251 & $0.7345^{*}$ \\
\hline 20 & 0.4737 & 0.3679 & 0.4957 \\
\hline 21 & 0.1520 & $0.6436^{*}$ & -0.0450 \\
\hline 22 & $0.6248^{*}$ & 0.3663 & 0.3900 \\
\hline 23 & 0.6105 * & 0.1097 & 0.3546 \\
\hline 24 & 0.2812 & 0.2782 & 0.5854 * \\
\hline 25 & 0.5652 & 0.5065 & 0.2725 \\
\hline 26 & 0.5958 * & 0.3288 & 0.3800 \\
\hline 27 & 0.1710 & 0.0552 & 0.7384 * \\
\hline \% expl. Var. & 26 & 14 & 19 \\
\hline
\end{tabular}

Note: The numbers 1,2,3, and 4 refer to the particular participants, in order to protect their privacy; * Represents a defining sort, which means one perspective. 


\section{References}

1. Fang, W.-T. Envisioning Environmental Literacy: Action and Outreach; Springer Nature: Singapore, 2020.

2. Ursul, A.; Ursul, T. Environmental education for sustainable development. Future Hum. Image 2018, 9 , 115-125. [CrossRef]

3. People's Republic of China. China's Agenda 21-White Paper on China's Population, Environment and Development; China Environmental Science Press: Beijing, China, 1994.

4. UNESCO. United Nations. United Nations Decade of Education for Sustainable Development (2005-2014): International Implementation Scheme; UNESCO: Paris, France, 2005.

5. Kopnina, H. Education for sustainable development (ESD): The turn away from 'environment' in environmental education? Environ. Educ. Res. 2012, 18, 699-717. [CrossRef]

6. Guo, F.; Lane, J.; Duan, Y.; Stoltman, J.P.; Khlebosolova, O.; Lei, H.; Zhou, W. Sustainable development in geography education for middle school in China. Sustainability 2018, 10, 3896. [CrossRef]

7. Russell, M.; Bebell, D.; O’Dwyer, L.; O'Connor, K. Examining teacher technology use: Implications for preservice and in-service teacher preparation. J. Teach. Educ. 2003, 54, 297-310. [CrossRef]

8. Goktas, Y.; Yildirim, S.; Yildirim, Z. Main barriers and possible enablers of icts integration into pre-service teacher education programs. J. Educ. Technol. Soc. 2009, 12, 193-204.

9. Han, I.; Shin, W.S. A multimedia case-based environment: Teaching technology integration to pre-service teachers. Educ. Technol. Int. 2011, 12, 1-20.

10. United Nations Educational Organization. Transforming Education: The Power of ICT Policies; Education Sector UNESCO: Paris, France, 2011.

11. Anderson, J.; Van Weert, T.; Duchâteau, C. Information and Communication Technology in Education: A Curriculum for Schools and Programme of Teacher Development; UNESCO: Paris, France, 2002.

12. Mayer, R.E. Multimedia learning. In Psychology of Learning and Motivation; Mayer, R.E., Ed.; Elsevier: Amsterdam, The Netherlands, 2002; pp. 85-139.

13. The State Council of the People's Republic of China. National Outline for Medium-And Long-Term Plan for Education Reform and Development (2010-2020). Available online: http://www.scio.gov.cn/xwfbh/xwbfbh/ wqfbh/33978/34777/xgzc34783/Document/1483157/1483157.htm (accessed on 13 May 2020).

14. Ministry of Education of the People's Republic of China. The Action Plan for Education Informatization 2.0. Available online: http://www.moe.gov.cn/srcsite/A16/s3342/201804/t20180425_334188.html (accessed on 13 May 2020).

15. Yusuf, M.O. Information and communication technology and education: Analysing the Nigerian national policy for information technology. Int. Educ. J. 2005, 6, 316-321.

16. Al-Ansari, H. Internet use by the faculty members of Kuwait University. Electron. Libr. 2006, 24, 791-803. [CrossRef]

17. Makrakis, V. ICTS as transformative enabling tools in education for sustainable development. In ICT in Education in Global Context; Huang Kinshuk, R., Price, J., Eds.; Springer: Berlin/Heidelberg, Germany, 2014; pp. 101-119.

18. Das, K. The role and impact of ICT in improving the quality of education: An overview. Intern. J. Innov. Stud. Soc. Hum. 2019, 4, 97-103.

19. Jonassen, D.H. Computers as Mindtools for Schools: Engaging Critical Thinking. Technol. Trends 1998, 2, 24-32. [CrossRef]

20. Wang, S.-K.; Hsu, H.-Y.; Reeves, T.C.; Coster, D.C. Professional development to enhance teachers' practices in using information and communication technologies (ICTS) as cognitive tools: Lessons learned from a design-based research study. Comp. Educ. 2014, 79, 101-115. [CrossRef]

21. Kopcha, T.J.; Neumann, K.L.; Ottenbreit-Leftwich, A.; Pitman, E. Process over product: The next evolution of our quest for technology integration. Educ. Technol. Res. Dev. 2020, 68, 729-749. [CrossRef]

22. Fanariotis, A.; Papathanasiou, T. In The use of Geographic Information Systems (GIS) in environmental education and awareness: The case of hiking trails in the island of Karpathos-Saria cluster. In Proceedings of the 7th International Conference on Information and Communication Technologies in Agriculture, Food and Environment (HAICTA), Kavala, Greece, 17-20 September 2015; pp. 333-340. 
23. Wang, S.; Hsu, H.; Campbell, T. Integrating technology into science instruction: Science learning, literacy, and the development of 21st century digital literacy. In High-Tech Teaching Success! A Step-by-Step Guide to Using Innovative Technology in Your Classroom; Besnoy, K.D., Lane, C., Eds.; Prufrock Press: Waco, TX, USA, 2009.

24. Campbell, T.; Wang, S.K.; Hsu, H.-Y.; Duffy, A.M.; Wolf, P.G. Learning with web tools, simulations, and other technologies in science classrooms. J. Sci. Educ. Technol. 2010, 19, 505-511. [CrossRef]

25. Tella, A.; Adu, E.O. Information communication technology (ict) and curriculum development: The challenges for education for sustainable development. Ind. J. Sci. Technol. 2009, 2, 55-59.

26. Vrasidas, C.; Zembylas, M.; Evagorou, M.; Avraamidou, L.; Aravi, C. ICT as a tool for environmental education, peace, and reconciliation. Educ. Media Int. 2007, 44, 129-140. [CrossRef]

27. Marçal, J.; Borges, M.M.; Viana, P. Learning physics through online video annotations. Educ. Knowl. Soc. 2020, 21, 14.

28. Baecher, L.; Rorimer, S.; Smith, L. Video-mediated teacher collaborative inquiry: Focus on English language learners. High Sch. J. 2012, 95, 49-61. [CrossRef]

29. Masats, D.; Dooly, M. Rethinking the use of video in teacher education: A holistic approach. Teach. Teach. Educ. 2011, 27, 1151-1162. [CrossRef]

30. Ambe, B.A.; Obeten, U.B. Instructional systems technology for teaching and learning environmental education. J. Soc. Sci. 2020, 48, 1538-1551.

31. Hill, J.L.; Nelson, A. New technology, new pedagogy? Employing video podcasts in learning and teaching about exotic ecosystems. Environ. Educ. Res. 2011, 17, 393-408. [CrossRef]

32. Rohwedder, W.; Alm, A. Using computers in environmental education: Interactive multimedia and on-line learning. In The Environmental Education Toolbox-EE Toolbox Workshop Resource Manual; Kendal/Hunt: Dubuque, IA, USA, 1994.

33. Teo, T.; Sang, G.; Mei, B.; Hoi, C.K.W. Investigating pre-service teachers' acceptance of web 2.0 technologies in their future teaching: A Chinese perspective. Interact. Learn. Environ. 2019, 27, 530-546. [CrossRef]

34. Davis, F.D. Perceived usefulness, perceived ease of use, and user acceptance of information technology. MIS Q. 1989, 13, 319-340. [CrossRef]

35. Davis, F.D.; Bagozzi, R.P.; Warshaw, P.R. Extrinsic and intrinsic motivation to use computers in the workplace 1. J. Appl. Soc. Psych. 1992, 22, 1111-1132. [CrossRef]

36. Bandura, A.; Ramachaudran, V.S. Encyclopedia of Human Behavior; Academic Press: New York, NY, USA, 1994; Volume 4, pp. 71-81.

37. Al-Awidi, H.M.; Alghazo, I.M. The effect of student teaching experience on preservice elementary teachers' self-efficacy beliefs for technology integration in the UAE. Educ. Technol. Res. Dev. 2012, 60, 923-941. [CrossRef]

38. Fishbein, M.; Ajzen, I. Belief, Attitude, Intention, and Behavior; Addison-Wesley: Reading, UK, 1975; pp. 913-927.

39. Trafimow, D.; Finlay, K.A. The importance of subjective norms for a minority of people: Between subjects and within-subjects analyses. Personal. Soc. Psych. Bull. 1996, 22, 820-828. [CrossRef]

40. Ybarra, O.; Trafimow, D. How priming the private self or collective self affects the relative weights of attitudes and subjective norms. Personal. Soc. Psych. Bull. 1998, 24, 362-370. [CrossRef]

41. Teo, T. Modelling technology acceptance in education: A study of pre-service teachers. Comp. Educ. 2009, 52, 302-312. [CrossRef]

42. Hsu, P.-S. Examining changes of preservice teachers' beliefs about technology integration during student teaching. J. Technol. Teach. Educ. 2013, 21, 27-48.

43. Kim, C.; Kim, M.K.; Lee, C.; Spector, J.M.; DeMeester, K. Teacher beliefs and technology integration. Teach. Teach. Educ. 2013, 29, 76-85. [CrossRef]

44. Liu, S.-H. A multivariate model of factors influencing technology use by preservice teachers during practice teaching. J. Educ. Technol. Soc. 2012, 15, 137-149.

45. Teo, T. Factors influencing teachers' intention to use technology: Model development and test. Comp. Educ. 2011, 57, 2432-2440. [CrossRef]

46. Han, I.; Shin, W.S.; Ko, Y. The effect of student teaching experience and teacher beliefs on pre-service teachers' self-efficacy and intention to use technology in teaching. Teach. Teachnol. 2017, 23, 829-842. [CrossRef]

47. Voogt, J.; Fisser, P.; Pareja Roblin, N.; Tondeur, J.; van Braak, J. Technological pedagogical content knowledge-A review of the literature. J. Comput. Assist. Learn. 2013, 29, 109-121. [CrossRef] 
48. Tan, L.; Chai, C.S.; Deng, F.; Zheng, C.P.; Drajati, N.A. Examining pre-service teachers' knowledge of teaching multimodal literacies: A validation of a TPACK survey. Educ. Media Int. 2019, 56, 285-299. [CrossRef]

49. Tseng, J.-J. Developing an instrument for assessing technological pedagogical content knowledge as perceived by efl students. Comp. Assist. Lang. Learn. 2016, 29, 302-315. [CrossRef]

50. Chang, C.-S.; Chen, T.-S.; Hsu, W.-H. The study on integrating webquest with mobile learning for environmental education. Comp. Educ. 2011, 57, 1228-1239. [CrossRef]

51. Hsiao, C.-Y.; Shih, P.-Y. Exploring the effectiveness of picture books for teaching young children the concepts of environmental protection. Intern. Res. Geogr. Environ. Educ. 2016, 25, 36-49. [CrossRef]

52. Genc, M. The project-based learning approach in environmental education. Intern. Res. Geogr. Environ. Educ. 2015, 24, 105-117. [CrossRef]

53. Derevenskaia, O. Active learning methods in environmental education of students. Procedia Soc. Behav. Sci. 2014, 131, 101-104. [CrossRef]

54. Ramsay, J.; Sorrell, E. Problem-based Learning: A Novel Approach to Teaching Safety, Health and Environmental Courses. In Proceedings of the ASSE Professional Development Conference and Exposition, Seattle, WA, USA, 11-14 June 2006.

55. Kwan, T.; So, M. Environmental learning using a problem-based approach in the field: A case study of a hong kong school. Intern. Res. Geogr. Environ. Educ. 2008, 17, 93-113. [CrossRef]

56. Thomas, G.; Munge, B. Best practice in outdoor environmental education fieldwork: Pedagogies to improve student learning. In Experiencing the Outdoors; Robertson, M., Lawrence, R., Heath, G., Eds.; Sense Publishers: Rotterdam, The Netherlands, 2015; pp. 165-176.

57. Fauville, G.; Lantz-Andersson, A.; Säljö, R. ICT tools in environmental education: Reviewing two newcomers to schools. Environ. Educ. Res. 2014, 20, 248-283. [CrossRef]

58. Resta, P.E. Information and Communication Technologies in Teacher Education: A Planning Guide; UNESCO: Paris, France, 2002.

59. Kalogiannakis, M.; Papadakis, S. Combining mobile technologies in environmental education: A Greek case study. Int. J. Mob. Learn. Org. 2017, 11, 108-130. [CrossRef]

60. Watts, S.; Stenner, P. Doing Q methodology: Theory, method and interpretation. Qual. Res. Psych. 2005, 2, 67-91. [CrossRef]

61. McKeown, B.; Thomas, D.B. Q Methodology; Sage Publications: Thousand Oaks, CA, USA, 2013; Volume 66.

62. E-Learning for ECNU. Available online: https://elearning.ecnu.edu.cn (accessed on 10 June 2020).

63. Sparks, K.M. Student Conceptions of Learning and the Approaches to Learning Adopted in an Introductory Science Course: AQ Methodology Study. Unpublished Ph.D. Thesis, Western Michigan University, Kalamazoo, MI, USA, 2013.

64. PQ Method Software. Available online: http://schmolck.org/qmethod/ (accessed on 6 June 2020).

65. Webler, T.; Danielson, S.; Tuler, S. Using Q Method to Reveal Social Perspectives in Environmental Research; Social and Environmental Research Institute: Greenfield, MA, USA, 2009; Volume 54, pp. 1-45.

66. Fraser, J.; Gupta, R.; Krasny, M.E. Practitioners' perspectives on the purpose of environmental education. Environ. Educ. Res. 2015, 21,777-800. [CrossRef]

67. Keiper, T.A. GIS for elementary students: An inquiry into a new approach to learning geography. J. Geogr. 1999, 98, 47-59. [CrossRef]

68. Baker, T.R. The Effects of Geographic Information System (GIS) Technologies on Students' Attitudes, Self-Efficacy, and Achievement in Middle School Science Classrooms. Unpublished Ph.D. Thesis, University of Kansas, Lawrence, KS, USA, 2002.

69. Kerski, J.J. The implementation and effectiveness of geographic information systems technology and methods in secondary education. J. Geogr. 2003, 102, 128-137. [CrossRef]

70. Johannson, T. GISAS Project: Geographical Information Systems Applications for Schools; University of Helsinki: Helsinki, Finland, 2006.

71. Marsh, M.; Golledge, R.; Battersby, S.E. Geospatial concept understanding and recognition in g6-college students: A preliminary argument for minimal GIS. Ann. Assoc. Am. Geogr. 2007, 97, 696-712. [CrossRef]

72. Demirci, A. Evaluating the implementation and effectiveness of GIS-based application in secondary school geography lessons. Am. J. Appl. Sci. 2008, 5, 169-178. [CrossRef]

73. Milson, A.; Kerski, J. Around the world with geospatial technologies. Soc. Educ. 2012, 76, 105-108. 
74. Milson, A.J.; Demirci, A.; Kerski, J.J. International Perspectives on Teaching and Learning with GIS in Secondary Schools; Springer: New York, NY, USA, 2012.

75. Kerski, J.J.; Demirci, A.; Milson, A.J. The global landscape of GIS in secondary education. J. Geogr. 2013, 112, 232-247. [CrossRef]

76. Demirci, A. Coğrafi bilgi sistemlerinin türkiye'deki yeni coğrafya dersi ğretim programına göre coğrafya derslerinde uygulanabilirliği. In Proceedings of the 4. Coğrafi Bilgi Sistemleri Bilişim Günleri, İstanbul, Turkey, 13-16 September 2006.

77. Aladag, E. An evaluation of geographic information systems in social studies lessons: Teachers' views. Educ. Sci. Theory Prac. 2014, 14, 1533-1539. [CrossRef]

78. Bednarz, S.W. Geographic information systems: A tool to support geography and environmental education? Geojournal 2004, 60, 191-199.

79. The Ministry of Education of the People's Republic of China. Geography Curriculum Standards for Senior Middle School; People's Education Press: Beijing, China, 2018.

80. Chien, Y.-T.; Chang, C.-Y.; Yeh, T.-K.; Chang, K.-E. Engaging pre-service science teachers to act as active designers of technology integration: A MAGDAIRE framework. Teach. Teach. Educ. 2012, 28, 578-588. [CrossRef]

81. Tondeur, J.; Van Braak, J.; Sang, G.; Voogt, J.; Fisser, P.; Ottenbreit-Leftwich, A. Preparing pre-service teachers to integrate technology in education: A synthesis of qualitative evidence. Comp. Educ. 2012, 59, 134-144. [CrossRef]

82. Mayer, R.E. Multimedia Learning; Cambridge University Press: Cambridge, UK, 2001.

83. UNESCO. Final Report, Intergovernmental Conference on Environmental Education, Tbilisi, 14-16 October 1977; UNESCO: Paris, France, 1978.

84. Hungerford, H.; Peyton, R.B.; Wilke, R.J. Goals for curriculum development in environmental education. J. Environ. Educ. 1980, 11, 42-47. [CrossRef]

85. Finger, G.; Jamieson-Proctor, R.; Cavanagh, R.; Albion, P.; Grimbeek, P.; Bond, T.; Fitzgerald, R.; Romeo, G.; Lloyd, M. Teaching teachers for the future (TTF) project TPACK survey: Summary of the key findings. Aust. Educ. Comp. 2013, 37, 13-25.

86. Sweeney, T.; Drummond, A. How prepared are our pre-service teachers to integrate technology? A pilot study. Aust. Educ. Comp 2013, 27, 117-123.

87. Mishra, P.; Koehler, M.J. Technological pedagogical content knowledge: A framework for teacher knowledge. Teach. Coll. Rec. 2006, 108, 1017-1054. [CrossRef] 